\title{
Determinants of Smallholder Maize Farmers' Choice of Selling Point: A Case of Kwanza District, Trans-Nzoia County, Kenya
}

\author{
Macharia Anthony* Mwangi Lenah \\ Department of Agricultural Economics and Agribusiness Management, Egerton University, P.O Box 536-20115, \\ Egerton, Kenya
}

\begin{abstract}
Commercialization of the smallholder maize sector in Kenya necessitates improving the ability of farmers to efficiently participate in both the formal and informal maize markets. Smallholder maize farmers of Kwanza district, Trans Nzoia County, however, have limited access to formal maize markets. This limits their competitiveness in the market hence a reduction in their returns. This study was aimed at assessing the factors that influence smallholder maize farmers' participation in formal maize markets in the region. Multistage sampling technique was used to select 196 smallholder maize farmers from the region. Primary data was collected using semi-structured questionnaires and the Probit model used to assess the factors influencing smallholder choice of selling point. Age of household head, household size and source of market information negatively influenced the probability of the farmers selling through formal maize markets. Education level, access to credit, sorting produce, tarpaulin ownership and output price however positively influenced the probability of selling through the formal maize markets. The study recommends policies that ensure the availability and access of appropriate market information. Farmers could also be assisted in the acquisition of tarpaulin used for drying maize and other necessary infrastructure to avoid losses due to the poor post-harvest handling of their output. This will greatly help in commercialising the smallholder maize sector in the region.
\end{abstract}

Keywords: Formal maize markets, Informal maize markets, Market participation, Transaction costs

DOI: $10.7176 / \mathrm{JESD} / 11-10-17$

Publication date:May $31^{\text {st }} 2020$

\section{Introduction}

Maize is important both as a food as well as a cash crop for many Kenyan smallholders. It accounts for the largest share of cultivated agricultural land in the country. More than half of small-scale farmers in Kenya engage in maize farming either as a pure stand or intercropped with other crops. The small and medium scale sector accounts for over three-quarters of all maize marketed in the country annually. The large scale sector produces the other quarter (Alene et al., 2008).

In Kenya, maize growing is mainly concentrated in the Rift Valley districts of Trans-Nzoia East and West, Wareng, Eldoret East and West, Nakuru and Kwanza, a region often referred to as the "Granary of Kenya" (Kwach, 2013).

Commercialization of the agricultural sector, in general, necessitates improving the ability of smallholders to participate in markets (both informal and formal ones) thereby improving their incomes and livelihoods in the long run (Jagwe et al., 2011). As such, integrating smallholder farmers into the market mechanism through increased market participation leads to higher living standards and reduces the vulnerability of farmers to marketing risks (Azam et al., 2012; Rhaghau et al., 2012 and Yamano and Arai, 2011).

The principle of agricultural commercialization is more than just marketing agricultural output. It is attained when a household's product choice and input use decisions are made with the main objective of profit maximisation. Commercial farming has considerable potential for unlocking suitable opportunities necessary for providing better incomes and sustainable livelihoods for small-scale farmers (Omiti et al., 2009). Markets and improved market access for poor rural households are essential for enhancing agriculture-based economic growth and increasing rural incomes. Increased commercialization of agriculture must be based upon the establishment of efficient and well-functioning markets and trading systems that keep transaction costs low, minimise risks and provide information to all actors especially those living in areas of marginal productivity and weak infrastructure (IFAD, 2003; World Bank, 2008).

In most developing economies, however, smallholder farmers find it difficult to participate in markets due to numerous constraints and barriers faced in accessing both input and output markets (Macharia et al., 2014). Omiti et al. (2009) found out that majority of rural farmers in Kenya produce low volumes of relatively low value and less perishable marketed surpluses. They mainly sell at the farm gate and in rural markets and do not effectively participate in urban markets that offer excellent opportunities for increasing their farm incomes. Costs associated with the exchange of goods and services inhibit the participation of smallholder farmers and traders in formal markets (Pingali et al., 2005). Alene et al. (2008) noted that although market reforms were introduced in many countries in Sub- Saharan Africa since the 1980's with a view of enhancing efficiency in markets, transaction costs in production and marketing have actually increased rather than declined. 
Smallholder maize farmers in Kwanza district, Trans Nzoia County, Kenya are in no way different from the rest of the farmers in developing countries, they face limited access to formal maize markets and rely mostly on the informal markets to dispose their surplus produce after harvest, this is despite the existence of a National Cereals and Produce Board depot at Kitale town, Kitale Industries and Dola maize millers among others that do commercial maize milling in the region. The main objective of this study was, thus, to give an insight on the possible constraints that hinder the smallholder maize farmers in Kwanza district, Trans Nzoia County, Kenya, from actively participating in the formal maize markets that usually offer higher prices as to the informal ones.

\section{Materials and methods}

The study was undertaken in Kwanza District of Trans Nzoia County, Kenya. The area is an upper midland AgroEcological Zone (UMZ) endowed with brown, red and clay soils. For sampling, multistage sampling design was used. Kwanza District was selected purposively because of the large number of smallholder maize farmers in the region. The district has two sub-counties, Kwanza and Endebess that were all selected. Kwanza sub-county has five wards while Endebess has three. Three wards in Kwanza and two in Endebess were selected purposively. Finally, the wards and villages to be sampled from each sub-county were selected randomly. Systematic random sampling, proportionate to the size of the ward, was used for selecting the respondents from each village. This gave a total of 72 farmers from Endebess and 124 farmers from Kwanza sub counties, respectively.

\section{Data analysis}

The framework as used in Jagwe et al. (2011) was adopted. Farmers decide on whether to sell their produce through the informal maize markets or formal ones. This decision is based on the margins obtainable while taking into account the costs involved in each market. Three scenarios, thus, guide the choice of selling point, assuming that farmers minimize costs and maximize gains. The first scenario is when prices offered at the formal maize markets minus producer prices and transaction costs incurred in selling the commodity exceed the prices offered at the informal markets minus producer prices and transaction costs incurred in selling the commodity. Farmers, therefore, opt to sell their output through the formal maize markets. The second scenario is where the formal maize market prices adjusted for producer prices and transaction costs are less than the adjusted informal maize market prices, farmers, therefore, are better off selling their output through the informal maize markets. Scenario three is where the farmer is indifferent between the two choices since the prices are equal in both cases.

The choice of selling point can ,therefore, be represented as a function of prices offered at the formal maize market $\left(p_{f m k t s}\right)$, informal maize market prices $\left(p_{\text {infmkts }}\right)$, transaction costs in informal maize markets $\left(T C_{\text {infmkts }}\right)$, transaction costs in formal maize markets $\left(T C_{f m k t s}\right)$ as well as other factors like the institutional and environmental factors represented by z. The relationship is thus depicted as:

$y=f\left(p_{\text {fmkts }}, p_{\text {infmkts }}, T C_{\text {fmkts }}, T C_{\text {infmkts }}, Z\right)$

The third scenario collapses into either scenario 1 or 2 . The situation $y=1$ represents scenario 1 whereby farmers opt to sell their produce through the formal maize markets. $Y=0$ represents the $2^{\text {nd }}$ scenario whereby farmers opt to sell their produce through the informal maize markets. The econometric specification thus follows a latent regression model specified as:

$y^{*}=\beta_{1} T C+\beta_{2} Z+e$.

Where $\mathrm{y}^{*}$ is a latent variable that is unobserved. $P$ denotes the maize price while $T C$ denotes the transaction costs incurred in selling maize. The dummy variable $\mathrm{y}$ is what is observed and is defined by:

$y=1$ if $y^{*}>0$ and $y=0$ otherwise

$B_{0}$ is parameter estimate for price variable, $B_{1}$ are parameter estimates for variables capturing transaction costs; $\mathrm{B}_{2}$ represents parameter estimates for variables capturing other factors affecting the choice of selling point e.g. the institutional and environmental factors. Since transaction costs are difficult to observe, the decision made by a farmer about the selling point are associated to the factors capturing transaction costs as well as other factors that may affect the choice. Marginal effects for the model were then specified as:

$\frac{\partial}{\partial T C_{i k}} \emptyset\left(T C_{i} \beta_{i}\right)=\emptyset\left(T C_{i}, \beta_{i}\right) \beta_{k}$

$\frac{\partial}{\partial z_{i k}} \emptyset\left(z_{i} \beta_{2}\right)=\varnothing\left(z_{i} \beta_{2}\right) \beta_{k}$

\subsection{Model specification}

The Probit model was specified as:

$\mathrm{Y}_{\mathrm{i}}(0,1)=\alpha_{0}+\alpha_{1}$ (Age) $+\alpha_{2}$ (Household_size $)+\alpha_{3}$ (Education) $+\alpha_{4}$ (Market information $)+\alpha_{5}$ (Output produced $)+$ $\alpha_{6}$ (Sort_produce) $+\alpha_{7}($ Credit_access $)+\alpha_{8}$ (Output_price $)+\alpha_{9}$ (Tarpaulin_ownership $)+\mu_{i}$ 
Table 1: Variables used in the Probit model

\begin{tabular}{|c|c|c|c|}
\hline Code & Variable & $\begin{array}{l}\text { Description and } \\
\text { Measurement }\end{array}$ & $\begin{array}{l}\text { Expected } \\
\text { sign }\end{array}$ \\
\hline (Participate) & $\begin{array}{l}\text { Dependent } \\
\text { If farmer participates in either informal/ formal } \\
\text { markets }\end{array}$ & \multicolumn{2}{|l|}{$\begin{array}{l}\text { Informal markets }=0 \text {,Formal } \\
\text { markets }=1\end{array}$} \\
\hline \multicolumn{4}{|c|}{ Independent } \\
\hline Age & Age of the household head & Years & - \\
\hline Household_size & Size of the household & $\begin{array}{l}\text { Number of household } \\
\text { members }\end{array}$ & +1 \\
\hline Education & Years of schooling for the household head & Years & + \\
\hline Market_information & Source of market information & $\begin{array}{l}\text { informal sources }=0 \text {, } \\
\text { Formal sources }=1\end{array}$ & + \\
\hline Output_produced & Output produced & $90 \mathrm{Kg}$ bags & + \\
\hline Sort_produce & If the farmer sorts produce before sell & $\mathrm{No}=0, \mathrm{Yes}=1$ & \\
\hline Credit_access & $\begin{array}{l}\text { If the farmer accessed credit the previous } \\
\text { season }\end{array}$ & $\mathrm{No}=0, \mathrm{Yes}=1$ & $\begin{array}{l}- \\
+\end{array}$ \\
\hline Out & Last price of maize output/ $90 \mathrm{~kg}$ bag & KES & + \\
\hline Tarpaulin_ownership & If farmer owns tarpaulin used for drying maize & $\mathrm{No}=0, \mathrm{Yes}=1$ & + \\
\hline
\end{tabular}

\section{Results and discussions}

4.1 Distribution of smallholder maize farmers in the different markets.

The distribution of smallholder farmers in the different maize markets was assessed and the results presented in Table 2.

Table 2: Distribution of smallholder farmers in the different market outlets

\begin{tabular}{lll}
\hline Market sold & Frequency & percentage \\
\hline Farm gate & 106 & 54.08 \\
Middlemen (Local market center) & 6 & 3.06 \\
Consumers (Local market center) & 3 & 1.53 \\
Local posho millers & 13 & 6.65 \\
Urban processors/ millers & 28 & 14.28 \\
National cereals and produce board & 22 & 11.22 \\
Non-participants & 18 & 9.18 \\
Total & 196 & 100.00 \\
\hline
\end{tabular}

Source: Field survey, May 2012

Out of all the farmers surveyed in the region, $54.08 \%$ sold their surplus output at the farm gate, $25.50 \%$ sold through formal maize markets (Urban processors/ millers and the N.C.P.B) while $9.18 \%$ of the respondents did not participate in maize markets at all. The other $11.24 \%$ were distributed between middlemen at the market Centre, consumers at the market Centre and local posho millers. This shows that a majority of the smallholder farmers sold their output at the farm gate. Further discussions with the farmers revealed that this was due to the convenience of selling at the farm gate as traders went directly to their homesteads and also bought maize in cash. The result concurs with Kirimi et al. (2011) who found out that smallholder maize sales go largely to small scale assemblers/ brokers who mostly buy at the farm gate. This was also probably due to the few transaction costs as well as other constraints faced when selling produce at the farm gate as compared to the other marketing channels.

\subsection{The effect of transaction costs on smallholder maize farmers' choice of selling point}

This section presents the results of the probit model. It shows the effect of a set of independent variables on the probability of either selling through the informal or formal maize markets. The dependent variable took a value of 0 or 1 in the model. 0 represented households that sold their output through the informal maize markets whereas 1 represented those who sold their output through the formal maize markets. Results of the model are as shown in Table 3. 
Table 3: The effect of transaction costs on smallholder maize farmers' choice of selling point

\begin{tabular}{lllll}
\hline Variables & Marginal effects & Coef. & Std. Err. & z \\
\hline Age & -0.007 & -0.028 & 0.013 & $-2.15^{* *}$ \\
Household Size & -0.009 & -0.034 & 0.035 & -0.98 \\
Education level & 0.033 & 0.126 & 0.040 & $3.13^{* * *}$ \\
Access to credit & 0.181 & 0.726 & 0.300 & $2.42^{* *}$ \\
Sort produce & 0.189 & 0.698 & 0.293 & $2.38^{* *}$ \\
Tarpaulin ownership & 0.166 & 0.661 & 0.293 & $2.26^{* *}$ \\
Market information source & -0.055 & -0.210 & 0.071 & $-2.96^{* * *}$ \\
Output price & 0.001 & 0.001 & 0.001 & 1.31 \\
Output produced & 0.034 & 0.132 & 0.152 & 0.87 \\
\hline
\end{tabular}

Number of obs $=178 ;$ Wald chi2 $(10)=56.28 ;$ Log pseudolikelihood $=-25.61 ;$ Prob $>$ chi2 $=0.0000$

${ }^{* * *, * *, *}$ Significance at 1,5 and $10 \%$ respectively, Source: Field survey, May 2012

Age of household head in years was used as a proxy to marketing experience. The increase in age of household head by 1 year reduced the probability of participating in formal maize markets by $0.70 \%$. This was probably due to the high-risk averse nature associated with older individuals as compared to the relatively younger individuals (Ayuya, 2010). It could also be due to the high transaction costs incurred in accessing the formal maize markets as revealed through open discussions with the farmers (Macharia, 2014). This result contradicted that of Jagwe $e t$ al. (2011) who found out that increase in age increased the probability of farmers participating in distant markets than selling at the farm gate because of negotiation skills acquired over time.

The education level of a household head had a positive coefficient and was statistically significant at $1 \%$ level. This shows that the more the number of years the household head spent in school, the higher was the probability of participating in high-value formal maize markets. An increase in education level by 1 year increased the probability of selling through formal maize markets by $3.30 \%$. This was probably due to the positive effect of education on individual exposure hence farmers could easily make rational decisions concerning the marketing of their output This result concurred with Sharma et al. (2009) who found out that relatively less educated farmers used traditional channels of marketing like neighbors and farm gate rather than selling to distant formal markets.

Access to credit increased the probability of participating in formal maize markets. Having access to credit increased the probability of participating in formal maize markets by $18.1 \%$. This may be attributed to the training offered by credit institutions on transforming agriculture into viable businesses, provision of market information by the institutions and also relaxation of the strain on cash to meet marketing costs, therefore, giving them ample time to source for high-value formal markets for their output. These results concur with Okoye et al. (2010) who found out that those households who had access to higher credit volumes had a higher probability of selling off farm rather than on farm.

Sorting produce before selling positively influenced the probability of selling through high-value formal maize markets. Sorting produce increased the probability of participating in high-value formal maize markets by approximately $18.9 \%$ and was statistically significant at $5 \%$ level. This was probably due to the fact that urban millers and the N.C.P.B (formal) required high-quality grain standards as compared to the informal markets, therefore, forcing farmers to go an extra step of sorting their produce in order to ensure their produce was accepted in these markets.

Owning tarpaulin used for drying maize increased the chances of participating in high-value formal maize markets by about $16.6 \%$. This was probably due to the fact that formal maize markets have a minimum moisture content required before purchasing farmers' produce as revealed through discussions with the interviewed farmers. Tarpaulins affect the quality of farmers' produce by ensuring that grains are not discoloured because of drying maize on bare ground or develop mold as a result of grain storage while still moist. Programs can thus be put forward by both public and private institutions like A.F.C, N.C.P.B and commercial banks for provision of tarpaulin to farmers with produce delivered to N.C.P.B or through the warehouse receipt system serving as collateral. Finally, informal sources of market information like friends, neighbors and other non-institutional sources were more effective in providing market information to the smallholder farmers. Further discussions with the farmers revealed that the farmers who did not have access to formal sources of market information obtained the information from informal sources such as neighbors, village mates and traders. From the results, obtaining information from informal sources reduced the probability of participating in formal markets by $5.50 \%$. These results concurred with Jagwe et al. (2011) who found out that households who received market information from village mates, neighbors and traders were less likely to travel to distant markets to sell their bananas. The information was mostly distorted, therefore, discouraging farmers from participating in the high-value formal maize markets.

\section{Conclusion and policy implication}

Commercialization of the smallholder maize sector in Kenya necessitates improving the ability of farmers to 
participate efficiently in both the formal and informal maize markets. This study was aimed at assessing the factors that hindered the smallholder maize farmers in Kwanza district, Trans-Nzoia County from actively participating in formal maize markets. Age of household head, household size and source of market information negatively influenced the probability of the farmers selling through the formal markets. Education level, access to credit, sorting produce, tarpaulin ownership and output price, however, positively influenced the probability of selling through formal maize markets. The study, therefore, recommends policies that ensure the availability and access of appropriate market information from the formal sources. Farmers could also be supported in the acquisition of tarpaulin used for drying maize and other necessary infrastructure to avoid losses due to the poor post-harvest handling of their output. This will greatly help in commercialising the smallholder maize sector in the region.

\section{ACKNOWLEDGMENT}

We are indebted to the African Economic Research Consortium (AERC) for their financial support in carrying out this study. Enumerators who collected the data are also highly acknowledged, finally, we wish to sincerely thank all the farmers who responded to our questions through both questionnaires and Focus Group Discussions. The opinions expressed in this study are those of the authors.

\section{References}

Alene, A., Manyong, V., Omanya, G., Mignouna, H., Bokanga, M. and Odhiambo, G. (2008). Smallholder market participation under transactions costs : Maize supply and fertiliser demand in Kenya. Food policy 33: 318-328.

Ayuya, O. (2010), "Evaluation of willingness to accept and adopt clean development mechanism projects among small-scale farmers in Njoro district, Kenya", MSc. Thesis, Department of Agricultural Economics and Agribusiness Management, Egerton University, Kenya.

Azam, S., Imai, K. and Gaiha, R. (2012), "Agricultural supply response and smallholders market participation: the case of Cambodia". Discussion Paper DP 2012-09. Kobe: Research Institute for Economics and Business Administration, Kobe University.

IFAD. (2003), "Promoting market access for the poor in order to achieve the millennium development goals", International Fund for Agricultural Development, roundtable discussion paper for the 25th-anniversary session of IFAD's governing council. February, 2003, available at: http://www.ifad.org/english/market/index.html (accessed 20th February 2012).

Jagwe, J. (2011). The impact of transaction costs on the participation of smallholder farmers and intermediaries in the banana markets of Burundi, DRC and Rwanda. Unpublished PHD. Thesis, Department of Agricultural Economics, Extension and Rural Development, University of Pretoria, South Africa.

Kirimi, L., Sitko, N., Jayne, S., Karin, F., Muyanga, M., Sheahan, M., Flock, J. and Bor, G. (2011). A farm gate to consumer value chain analysis of Kenya's maize marketing system, Working paper No. 111, MSU international development.

Kwach, D. (2013). Effect of fertiliser input subsidy on maize production in Kenya: The case of Wareng District. Unpublished M.A Thesis, School of Economics, University of Nairobi, Kenya.

Macharia, M.A., Mshenga, P.M., Ngigi, M., Gido, O.E. and Kiprop, K.J. (2014), "Effect of transaction costs on smallholder maize market participation: Case of Kwanza District, Trans Nzoia County, Kenya", International Journal of Development and Sustainability, Vol. 3 No. 4, pp. 715-725.

Okoye, B., Onyenweaku, C. and Ukoha, O. (2010), "An ordered Probit model analysis of transaction costs and market participation by smallholder cassava farmers in South- Eastern Nigeria", available at: http://mpra.ub.uni-muenchen.de/26114/MPRA Paper No. 26114, (accessed 13th October 2012).

Omiti, J., Otieno, D., Nyanamba, T. and Mc Cullough, E. (2009), "Factors influencing intensity of market participation by smallholder farmers, a case study of rural and peri-urban areas of Kenya", Afrijare, Vol. 3 No. 1, pp. 11-15.

Pingali, P., Meijer, M. and Khwaja, Y. (2005). Commercialising small farms: Reducing transaction costs. ESA Working Paper No. 05-08: Online available: ftp://ftp.fao.org/docrep/fao/008/af144e/af144e00.pdf. Accessed 10 October 2011

Rhaghau, G., Shafiul, D. and Katsushi, S. (2012). Agriculture, markets and poverty - A comparative analysis of Laos and Cambodia, Research institute for economics and business administration, Discussion paper series, RIEB, Kobe university, Japan.

Sharma, P., Kumar, K. and Singh, R. (2009). Determinants of small-scale farmer inclusion in emerging modern agrifood Markets: A study of the Dairy Industry in India. Indian Institute of Management. Working Paper No.2009-02-01.

World Bank (2008), "World development report: agriculture for development", The World Bank, Washington D.C. Yamano, T and Arai, A. (2011) "The maize farm-market price spread in Kenya and Uganda" In: Yamano, T., Otsuka, K. and Place, F. (Eds.). Emerging development of agriculture in East Africa -Market, Soil and Innovations, Springer: London 